А. М. Денисенко, Г. С. Грінченко, В. М. Бурдейна, Ю. С. Лис

Українська інженерно-педагогічна академія, Харків, Україна

\title{
МЕТОДИКА УПРАВЛІННЯ РИЗИКАМИ ДЛЯ СИСТЕМИ УПРАВЛІННЯ ЯКІСТЮ ПРИ ВИГОТОВЛЕННІ ВИРОБІВ МЕДИЧНОГО ПРИЗНАЧЕННЯ
}

\begin{abstract}
Метою статті є розробка методичних рекомендацій, щодо створення методики управління ризиками при розробленні, підтриманні та управлінні системою управління якістю, відповідно до вимог міжнародного стандарту ISO 13485:2016 «Вироби медичні. Системи управління якістю. Вимоги щодо регулювання». У статті розглянуті етапи та алгоритм створення методики оцінювання та управління ризиками, яка необхідна для створення системи управління якістю при виробництві виробів медичного призначення. Для оцінювання ймовірності настання збитку застосовують постійну 5-ти бальну шкалу описових рівнів ймовірності, яка визначається і характеризується експертами перед проведенням оцінки ймовірностей збитків встановлених небезпек, що виникають при використання певного медичного виробу.
\end{abstract}

Кл юч ов і слов а: медичні вироби; вироби медичного призначення; життєвий цикл продукції; значення медичної користі; управління ризиками; управління якістю; контрольовані ризики.

\section{Вступ}

Однією з найбільш інноваційних галузей у світовій промисловості є виробництво медичних виробів (MB), що включає в себе медичну техніку. Так як іiї основним призначенням $є$ поліпшення якості і збільшення тривалості людського життя, то вона знаходиться в постійному полі зору регулюючих органів. В Україні державний нагляд за обігом МВ здійснює Державнаслужба України 3 лікарських засобів.

Законодавством України у сфері технічних регламентів та оцінки відповідності встановлено, що всі МВ, що знаходяться в обігу на ринку України, повинні проходити процедуру оцінки відповідності та відповідати таким нормативним вимогам: Технічному регламенту щодо медичних виробів, затвердженому постановою Кабінету Міністрів України від 02.10.2013 № 753, Технічному регламенту щодо MB для діагностики in vitro, затвердженому постановою Кабінету Міністрів України від 02.10.2013 № 754 , та Технічному регламенту щодо активних МB, які імплантують, затвердженому постановою Кабінету Міністрів України від 02.10.2013 № 755. Відповідність продукції вимогам технічних регламентів забезпечується шляхом застосування національних стандартів, що діють у цій сфері [1].

В Україні діє міжнародний стандарт [2], який установлює вимоги до системи управління якістю, які можуть застосовуватися підприємством повного циклу виробництва $\mathrm{MB}$, а саме: для проектування та розроблення, виробництва, зберігання та дистрибуції, монтажу та обслуговування, а також кінцевого демонтажу та утилізації MB та для проектування, розроблення й надання пов'язаних з ними послуг (наприклад, послуг технічної підтримки). Вимоги цього міжнародного стандарту можуть також застосовувати постачальники або інші зовнішні сторони, що надають свої послуги при виробництві продукції (наприклад, постачання сировини, комплектуючих, вузлів, медичних приладів, надання послуг зі стерилізації, калібрування, послуг дистрибуції, послуг 3 технічного обслуговування) [2].
Для оцінювання ризиків, у стандарті [2] $є$ посилання на стандарт [3], який вимагає від організації встановити, документувати і підтримувати в робочому стані безперервний процес ідентифікації небезпек (ризиків), пов'язаних з МB, визначення та оцінювання супутніх ризиків, управління даними ризиками i моніторингу результативності такого управління протягом усього життевого циклу МВ. Цей процес повинен включати наступні елементи: аналіз ризику; оцінювання ризику та управління ризиком.

Для оцінювання ризиків розроблено міжнародний стандарт [4]. Цей документ надає рекомендації 3 управління ризиками, 3 якими стикаються організації. Порядок застосування даних рекомендацій може бути адаптований для будь-якої організації і її контексту. Цей стандарт містить загальний підхід до управління будь-якими ризиками і не $\epsilon$ вузькоспеціальних або галузевим. Він може застосовуватися протягом усього життєвого циклу організації і для будь-якої діяльності, включаючи прийняття рішень на всіх рівнях.

Для розвивитку стандарту [4] було розроблено стандарт [5], який подає настанови щодо вибору та застосування систематичних методів загального оцінювання ризику, що сприяє іншим видам діяльності з керування ризиками.

Стандарт [5] має загальний характер, тому він може слугувати настановою для різних типів систем управління. Організації, що розробляють системи управління якістю згідно [2] повинні розробити свої задокументовані методики щодо оцінювання та управління ризиками.

Оціцнюванням та принципами кваліметрії зайняли важливу позицію українські науковці [6-10], але на сьгоднішній день не розроблено методики застосування принципів управління ризиками для промислових підприємств, повязаних 3 виробництвом продукції медичного призначення.

Метою роботи є створення універсальної методики оцінювання ризиків для розробки та впровадження системи управління якістю при виробництві виробів медичного призначення. 


\section{Основна частина}

Для ініціації робіт з управління ризиками наказом Директора на підприємстві створюється робоча i експертна групи з управління ризиками, до складуякої включають провідних фахівців, що мають високу кваліфікацію, досвід в галузі побудови і управління системи менеджменту якості і здатних виконати роботи по розробці системи управління і безперервного контролю ризиків. Робоча група розробляє проект Плану управління ризиками медичних виробів для кожного виду продукції.

Першим етапом при визначенні небезпек пов'язаних з кожним видом MB $є$ встановлення його властивостей, якісних і кількісних ознак і функцій, які могли б негативно вплинути на безпеку використання даного МВ, далі - чинників небезпеки. При цьому повинні бути визначені і вказані встановлені або спостерігаються граничні значення і характеристики для цих факторів МВ. В результаті аналізу цих факторів повинен, бути розроблений перелік відомих і передбачуваних небезпек, пов'язаних з використанням MB згідно з призначенням. Визначення факторів MB і пов'язаних з ним потенційних небезпек проводять відповідно до вимог Технічного регламенту щодо медичних виробів.

Для кожної встановленої небезпеки визначають наслідки реалізації небезпеки та причини і механізми виникнення небезпеки, а також проводять заходи щодо запобігання або зниження ризику. Отримані дані заносять до протоколу «Аналіз, оцінка і контроль ризиків», який оформлюється для кожної небезпеки кожного виду МВ. На підставі всебічного розгляду перерахованих вище даних проводять оцінку ризику (розрахунок індексу ризику), який $є$ комбінацією двох компонентів: ступеня тяжкості можливої шкоди $(S)$ і ймовірності настання збитку $(P)$.

Для оцінки ймовірності настання збитку застосовують постійну 5-ти бальну шкалу описових рівнів ймовірності, яка визначається і характеризується експертами перед проведенням оцінки ймовірностей збитків встановлених небезпек, що виникають при використання певного МВ. Дана шкала у вигляді таблиці наводиться в Плані управління ризиками для кожного виду MB. Характеристики кожного рівня ймовірності повинні дозволяти достатньо чітко відносити ймовірність того чи іншого збитку до якого-небудь 3 5-ти прийнятих рівнів виходячи 3 інформації про фактор небезпеки, причини, механізми та заходи щодо запобігання (зниження ймовірності). Ранжування рівнів імовірності $\epsilon$ відносним і може не відображати дійсну ймовірність виникнення збитків. Проте, у міру обліку минулого і накопичення нового досвіду, аналізу статистичних даних, кількісний вміст рівнів і оцінка ймовірності збитку повинні поступово уточнятися.

При цьому слід відповісти на наступні питання: Супроводжується наступ небезпеки якимись ознаками або вони сигналізують (попереджують) про неї?; Чи настає небезпека незалежно від дій виробника, контролера, користувача?; Чи настає небезпека в результаті однієї помилки виробника або конт- ролера або користувача?; Чи настає небезпека тільки за умови багаторазової помилки?.

Для оцінки ймовірності небажаної події застосовують такі способи: застосування накопичених значущих даних; передбачення ймовірності з використанням аналітичної техніки і техніки симуляції; оцінку рівня можливості експертами.

Для ряду випадків ймовірність виникнення збитків може бути розрахована строго кількісно на основі накопичених значущих даних. В цьому випадку для зіставлення строго розрахованих значень ймовірності з використовуваними в даній методиці якості 5-ю описовими рівнями ймовірності визначаються діапазони значень ймовірності, які відповідають кожному з 5-ти рівнів. Дана робота здійснюється із залученням експертів (фахівці з великим досвідом в області МВ). При проведенні оцінки ймовірності спочатку проводиться статистична оцінка значущості вихідних даних і строгий розрахунок значень ймовірності (табл. 1).

Таблияя $1-\begin{aligned} & \text { Шкала напівкількісних рівнів } \\
& \text { ймовірності настання збитку }\end{aligned}$
\begin{tabular}{|c|c|c|c|}
\hline $\begin{array}{c}\text { Оцін- } \\
\text { ка }\end{array}$ & $\begin{array}{c}\text { Ймовірність } \\
\text { настання збитку }\end{array}$ & $\begin{array}{c}\text { Діапазон } \\
\text { ймовірності }\end{array}$ & Визначення \\
\hline P1 & Малоймовірне & $<5 \times 10^{-7}$ & $\begin{array}{c}\text { Малоймовірне, } \\
\text { але можливе }\end{array}$ \\
\hline P2 & Дуже низька & $5 \times 10^{-7}-5 \times 10^{-5}$ & $\begin{array}{c}\text { Ймовірне } \\
\text { виникнення }\end{array}$ \\
\hline Р3 & Низька & $5 \times 10^{-5}-5 \times 10^{-3}$ & $\begin{array}{c}\text { Ймовірні пооди- } \\
\text { нокі випадки }\end{array}$ \\
\hline Р4 & Висока & $5 \times 10^{-3}-5 \times 10^{-1}$ & $\begin{array}{c}\text { Буде виникати } \\
\text { не один раз }\end{array}$ \\
\hline Р5 & Дуже висока & $>/=5 \times 10^{-1}$ & $\begin{array}{c}\text { Велика ймовір- } \\
\text { ність виникнення }\end{array}$ \\
\hline
\end{tabular}

Для оцінювання ступеня важкості можливої шкоди $(S)$ також застосовують систему 5 ранжируваних рівнів цього показника, які визначаються $\mathrm{i}$ характеризуються експертами перед проведенням оцінки ступеня важкості ймовірних збитків від використання певного МВ. Така система в вигляді таблиці наводяться в Плані управління ризиками для кожного виду МВ. Характеристики кожного рівня ступеня важкості (розроблені експертами) повинні дозволяти достатньо чітко відносити ступінь важкості того чи іншого збитку до якогонебудь 3 5-ти прийнятих рівнів виходячи з опису цього збитку. Ступінь важкості ймовірного збитку це оцінка найбільш серйозного наслідки небезпеки (якщо їх більше однієі). Аналіз ступеня важкості та ймовірності шкоди повинен бути зроблений так, щоб полегшити находження рішення щодо зниження ризику шляхом зменшення ступеня важкості наслідків небезпеки або зниження ймовірності їх виникнення (табл. 2).

Користуючись системою 5-ти рівневих критеріїв (5-ти бальною системою) для оцінки ймовірності збитків і їх ступеня тяжкості розраховують матрицю оцінки ризику, яка має вигляд, як на табл. 3. Ці зони $\epsilon$ діапазони значень ризику, відповідні вищенаведеним рівнями ризиків. Дана матриця заноситься до Плану управління ризиками для кожного виду МВ. 
Таблиця 2 - Шкала якісних рівнів ступеня важкості шкоди

\begin{tabular}{|c|c|l|}
\hline $\begin{array}{c}\text { Oцін- } \\
\text { ка }\end{array}$ & $\begin{array}{c}\text { Ступень } \\
\text { важкості } \\
\text { шкоди }\end{array}$ & \multicolumn{1}{|c|}{ Визначення } \\
\hline S1 & $\begin{array}{l}\text { Дуже } \\
\text { низька }\end{array}$ & $\begin{array}{l}\text { Відсутність пошкоджень і погіршення } \\
\text { 3доров'я, але нанесення незначної } \\
\text { моральної або матеріальної шкоди }\end{array}$ \\
\hline S2 & Низька & $\begin{array}{l}\text { Незначні пошкодження без ускладнень } \\
\text { i погіршення здоров'я, нанесення знач- } \\
\text { ної моральної або матеріальної шкоди }\end{array}$ \\
\hline S3 & Помірна & $\begin{array}{l}\text { Захворювання, серйозне пошкодження, } \\
\text { що закінчилося повним одужанням і не } \\
\text { спричинило ускладнень }\end{array}$ \\
\hline S4 & Значна & $\begin{array}{l}\text { Захворювання, серйозне пошкодження, } \\
\text { що закінчилося ускладненнями і знач- } \\
\text { ним погіршенням здоров'я }\end{array}$ \\
\hline S5 & $\begin{array}{l}\text { Кри- } \\
\text { тична }\end{array}$ & $\begin{array}{l}\text { Летальний результат, незворотні по- } \\
\text { шкодження користувача або пацієнта }\end{array}$ \\
\hline
\end{tabular}

Таблиця 3 - Матриця оцінки ризику

\begin{tabular}{|l|l|l|l|l|l|}
\hline & S1 & S2 & S3 & S4 & S5 \\
\hline P5 & & & & & \\
\hline P4 & & & & & \\
\hline P3 & & & & & \\
\hline P2 & & & & & \\
\hline P1 & & & & & \\
\hline
\end{tabular}

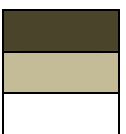

- Ризик неприпустимий (РН)

- Ризик прийнятний на практиці (РПП)

- Ризик прийнятний (РП)

На підставі висновку по кожному ризику приймається одне 3 двох варіантів рішень:

1. Оцінений ризик досить малий (значення індексу ризику потрапляє в діапазон рівня прийнятних ризиків), ним можна знехтувати і не слід розробляти заходів по його зниження.

2. Ризик досить великий і необхідно визначити і здійснити заходи для його контролю.

Якщо на підставі аналізу та оцінки ризиків прийнято рішення про необхідність подальшого зниження рівня ризику для певної небезпеки необхідно вжити заходів для його контролю 3 метою доведення до рівня прийнятного або прийнятного на практиці низького.

Заходи щодо попередження, зниження або утримування в жорстких межах контрольованих ризиків розробляються фахівцями експертної та робочої груп. Розробка зазначених заходів починається з вивчення можливості зниження рівня ризику за умови прийняття всіх доступних підприємству заходів.

У разі якщо встановлюється, що знизити індекс ризику до рівня прийнятних ризиків неможливо, то розробляються заходи щодо зниження індексу ризику до рівня прийнятних на практиці низьких ризиків. Розроблені заходи заносяться в таблицю документу «Аналіз, оцінка і контроль ризиків».
Після виконання вищевказаних дій проводиться оцінка залишкових ризиків 3 урахуванням вже вжитих заходів щодо запобігання або зниження ризику.

Отримані дані характеризують рівень залишкових ризиків (S1, P1, (S1xP1)) після вжиття заходів щодо зниження ризиків. На підставі аналізу отриманих результатів приймається одне 3 двох варіантів рішень:

1. Оцінений залишковий ризик досить малий та ним можна знехтувати і не слід розробляти нових заходів по його зниженню.

2. Ризик досить великий і значення індексу ризику потрапляє в діапазон прийнятних на практиці низьких ризиків. У цьому випадку ризик і медична користь повинні бути зрівняні для визнання допустимості чи не припустимо ризику. Прийняті рішення заносяться в таблицю документа «Аналіз, оцінка i контроль ризиків» даного МВ.

Значення критерію медичної користі від використання даного МВ встановлюється експертами. При цьому повинно забезпечуватися чисельну приведення значення даного критерію до величини, порівнянної з діапазоном значень індексів ризику.

Для кожного залишкового ризику, подальше зниження величини індексу якого неможливо, членами групи управління ризиками проводиться порівняння значення індексу ризику і критерію медичної користі. У разі, якщо значення критерію медичної користі перевищує значення індексу ризику, то приймається рішення про допустимість даного залишкового ризику.

У зворотному випадку такий ризик визнається неприпустимим. Результати порівняння заносяться в таблицю документа «Аналіз, оцінка і контроль ризиків».

В результаті вжиття заходів щодо зниження ризиків на етапі 6 могли виникнути зміни в конструкції MB, процесі його виробництва, контролю та використання. Ці зміни можуть визначати нові ознаки і функції - нові чинники небезпеки і пов'язані 3 ними ризики. Для посвідчення в тому що, в процесі прийняття заходів щодо запобігання або зниження ризиків не виникло ніяких нових факторів небезпеки, членами робочої групи управлення ризиками проводиться повторний аналіз ризиків.

Після проведення заходів щодо запобігання i зниження ризиків, визначених при організації контролю ризиків, а також проведення оцінки кожного залишкового ризику членами робочої групи з управління ризиками здійснюється загальна оцінка залишкового ризику.

Для визначення критеріїв прийнятність загального залишкового ризику експертами розробляється відповідна шкала для кожного МВ. Максимальне значення шкали отримують підсумовуванням за всіма встановленими небезпекам значень індексів ризику.

Отриману шкалу експерти поділяють на діапазони, відповідні прийнятним ризикам, прийнятним на практиці ризикам і неприйнятним ризикам. Дана шкала заноситься до Плану (для кожного МВ). Чле- 
нами робочої групи управління ризиками розраховується сума залишкових ризиків для даного МВ i визначається рівень загального залишкового ризику відповідно до наведеної в Плані шкали.

Вихідні дані і результати оцінки загального залишкового ризику виноситься на нараду з якості, на якій приймається рішення про допустимість загального залишкового ризику для даного МВ.

Результати оцінки загального залишкового ризику і рішення про прийнятність його величини заносяться до «Звіту про управління ризиками».

Оцінка досвіду і переоцінка ризиків здійснюється в разі:

- систематичного перегляду «Плану управління ризиками для кожного МВ»;

- при зміні національної або міжнародної нормативної бази в сфері ризиків і безпеки IVD;

- отриманні незадовільних результатів моніторингу процесу управління ризиками для даного МB;

- виникненні небезпечних ситуацій або збитку у споживачів при використанні продукції підприємства.

При цьому членами робочої групи з управління ризиками проводиться вивчення і аналіз змін в конструкції МВ, технології його виробництва і контролю, способів застосування.

Однією 3 умов дієвості та результативності управління ризиками на підприємстві є налагодження та підтримка належної системи реалізації, контролю та оцінки цього процесу.

Функція організації процесу управління ризиками, забезпечення його необхідними ресурсами, в тому числі кваліфікованим персоналом, систематичного контролю і оцінки діяльності 3 управління ризиками знаходиться в сфері відповідальності вищого керівництва. Процес управління ризиками інтегрований в загальну систему взаємодіючих процесів СУЯ підприємства, в зв'язку з чим його реалізація, оцінка та контроль ефективності здійснюється на наступних рівнях функціонування системи менеджменту якості:

1. Збір, аналіз і статистична обробка даних по небезпечних ситуацій, оцінки ризиків та їх допустимість. Оперативне управління отриманої інформації здійснюється на всіх стадіях життєвого циклу кожного виду МВ - розробки і проектування, виробництва, приймальних випробувань, доставки, використання і утилізації у споживача. 3бір і первинний аналіз даних на кожній стадії життєвого циклу продукції організовує та контролює профільний керівник цієї стадією циклу. Інформація в письмовому вигляді передається представнику керівництва 3 якості - керівнику робочої групи з управління ризиками, який організовує детальний аналіз отриманої інформації, розробку коригувальних заходів щодо їх зниження та інші дії з управління ризиками. До цієї роботи крім робочої групи залучаються керівники та фахівці експертної групи. Розроблені пропозиції на проведення коригувальних дій, включаючи необхідні ресурси, передаються на розгляд і аналіз на нарада 3 якості, де приймається остаточне рішення про їх проведення.
2. Моніторинг та вимірювання процесу. Моніторинг процесу управління ризиками здійснюють працівники групи моніторингу та аудиту. Моніторинг процесу повинен проводитися не рідше 1 разу на рік. До проведення моніторингу повинні залучатися провідні фахівці робочої та експертної груп. Результати моніторингу документуються і передаються представнику керівництва 3 якості, який представляє їх на нараді з якості для детального аналізу і прийняття рішень (див. Аналіз з боку вищого керівництва).

3. Аналіз з боку вищого керівництва. Результати збору, аналізу та статистичної обробки даних щодо ризиків, моніторингу та вимірювання цього процесу передаються представнику керівництва 3 якості, який організовує детальний аналіз отриманої інформації, розробку пропозицій на проведення запобіжних та коригувальних дій щодо зниження ризиків і запобігання небезпечних ситуацій. До виконання цих робіт залучаються фахівці робочої та експертної груп.

Результати аналізу та пропозиції представник керівництва 3 якості представляє на нарада 3 якості для всебічного вивчення, оцінки та прийняття рішень, які затверджуються директором.

4. Управління ресурсами. При прийнятті нових рішень 3 управління ризиками вище керівництво повинно чітко визначити і виділити ресурси, необхідні для ефективного виконання запланованих дій.

У тому числі визначається компетентний персонал, розподіляється відповідальність і повноваження, необхідна інфраструктура і засоби на закупівлі.

5. Процеси життєвого циклу продукції.

Реалізація прийнятих рішень 3 управління ризиками здійснюється на етапі життєвого циклу продукції, якого стосується дане рішення. Однак важливо, щоб діяльність $з$ управління ризиками охоплювала всі етапи життєвого циклу продукції:

- розробки і проектування;

- виробництва;

- контролю;

- використання й сервісного обслуговування у споживача.

В процесі реалізації прийнятих коригувальних дій знову повинен бути здійснений процес збору, аналізу та статистичної обробки даних і всі наступні етапи циклу СУЯ. Алгоритм оцінювання та управління ризиками при виготовленні МВ показано на рис. 1.

\section{Висновки}

Запропоновані методичні рекомендації щодо створення методики управління ризиками при розробленні, підтриманні та управлінні системою управління якістю, відповідно до вимог міжнародного стандарту ISO 13485:2016 «Вироби медичні. Системи управління якістю. Вимоги щодо регулювання».

У статті розглянуті етапи та алгоритм створення методики оцінювання та управління ризиками, яка необхідна для створення системи управління 


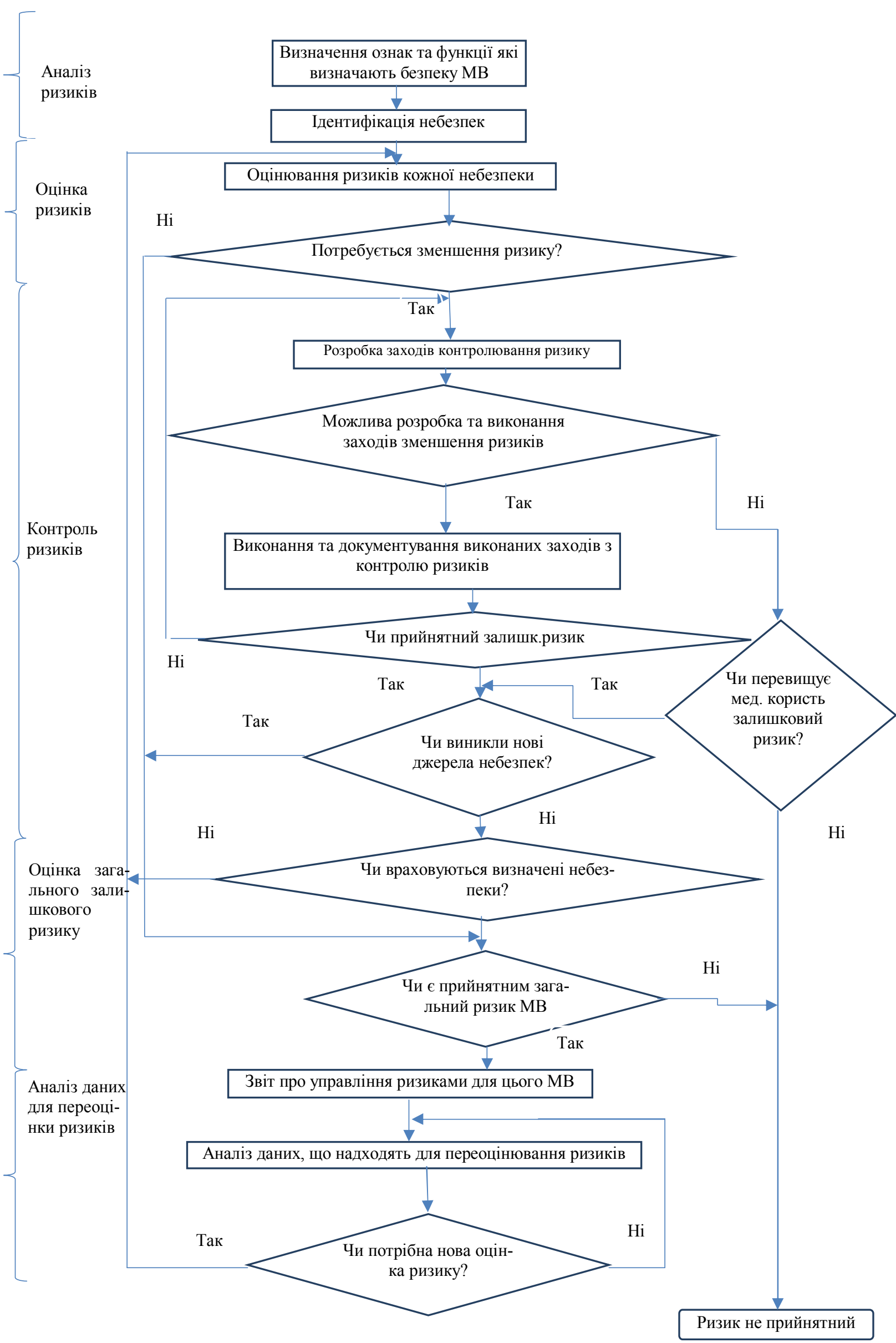

Рис. 1. Алгоритм оцінювання та управління ризиками при виготовленні МВ 
якістю при виробництві виробів медичного призначення.

Для оцінювання ймовірності настання збитку застосовують постійну 5-ти бальну шкалу описових рівнів ймовірності, яка визначається і характеризується експертами перед проведенням оцінки ймовірностей збитків встановлених небезпек, що виникають при використання певного медичного виробу.

\section{СПИСОК ЛІТЕРАТУРИ}

1. Співак Н. Огляд актуальних питань ринку медичних виробів [Електронний ресурс]. - 2017. - Режим доступу до pecypcy: https://eba.com.ua/article/review-current-issues-medical-products-market.

2. ДСТУ EN ISO 13485:2015 Медичні вироби. Система управління якістю. Вимоги до регулювання (EN ISO 13485:2012, IDT; ISO 13485:2003, IDT) [Чинний від 2016-01-01]. Київ, 2015. 87 с.

3. ДСТУ EN ISO 14971:2015 Вироби медичні. Настанови щодо управління ризиком. [Чинний від 2016-01-01]. Київ, 2015. $104 \mathrm{c}$.

4. ДСТУ ISO 31000:2018 Менеджмент ризиків. Принципи та настанови. [Чинний від 2019-01-01]. Київ, 2018.

5. ДСТУ IEC/ISO 31010:2013 Керування ризиком. Методи загального оцінювання ризику. [Чинний від 2014-07-01]. Київ, 2015. 80 с.

6. Трищ Р. М. Обобщённая точечная и интервальная оценки качества изготовления детали ДВС / Р. М. Трищ, Е. А. Слитюк. // Восточно-Европейский журнал передовых технологий. - 2006. - №1/2 (19). - С. $63-67$.

7. Арпентьєв Б. М. Особливості систем управління якістю механозбирального виробництва / Б. М. Арпентьєв, Р. М. Тріщ. // Стандартизація. Сертифікація. Якість. - 2005. - №1. - С. 68 - 72.

8. Трищ Р. М. Оценка модели точности изготовления деталей на адекватность // Вісник НТУ „ХПІ”. Збірник наукових праць. Тематичний випуск: Нові рішення в сучасних технологіях. - Харків: НТУ „ХПІ”. - 2005. - № 57 - С. 61-65.

9. Трищ Р. М. Определение закона распределения точности механической обработки // Восточно-Европейский журнал передовых технологий. - Харьков. - 2005. - № 5/2 (17) - С. 46-48.

10. Трищ Р. М. Применение чувствительных характеристик для определения модели точности изготовления деталей // Восточно-Европейский журнал передовых технологий. - Харьков. - 2005. - № 6/2 (18) - С. 11-13.

Рецензент: д-р техн. наук, проф. Г. І. Канюк, Українська інженерно-педагогічна академія, Харків Received (Надійшла) 15.04.2019

Accepted for publication (Прийнята до друку) 29.05.2019

\section{Методика управления рисками для системы управления качества при изготовлении изделий медицинского назначения}

А. Н. Денисенко, А. С. Гринченко, В. М. Бурдейная, Ю. С. Лис

Целью статьи является методические рекомендации по созданию методики управления рисками при разработке, поддержке и управлении системой управления качеством в соответствии с требованиями международного стандарта ISO 13485:2016 «Изделия медицинские. Системы управления качеством. Требования по регулированию». Результаты. В статье рассмотрены этапы и алгоритм создания методики оценки и управления рисками, которая необходима для создания системы управления качеством при производстве изделий медицинского назначения. Для оценки вероятности наступления ущерба применяют постоянную 5-ти балльную шкалу описательных уровней вероятности, которая определяется и характеризуется экспертами перед проведением оценки вероятностей убытков установленных опасностей, возникающих при использовании определенного медицинского изделия. Выводы.

Ключевы е слов а: медицинские изделия; изделия медицинского назначения; жизненный цикл продукции; значение медицинской пользы; управление рисками; управление качеством; контролируемые риски.

\section{Method of risk management for the quality management system in the manufacture of medical devices}

A. Denysenko, H. Hrinchenko, V. Burdeina, Y. Lys

The purpose of the article is to develop guidelines for creating a risk management methodology in the development, support and management of a quality management system in accordance with the requirements of the international standard ISO 13485: 2016 "Medical devices. Quality management systems. Requirements for regulation. Analyzed the legislation of Ukraine in the field of technical regulations and conformity assessment of medical devices. Analyzed international standards for assessing the risks associated with the production of medical devices. It is determined that the methods of application of risk management principles for industrial enterprises related to the production of medical products have not been developed. The article describes the steps and algorithm for creating a methodology for assessing and managing risks, which is necessary to create a quality management system in the manufacture of medical products. To assess the likelihood of damage, a constant five-point scale of descriptive levels of probability is used, which is determined and characterized by experts before assessing the likelihood of loss of identified hazards arising from the use of a particular medical device.

Keywords : medical devices; medical products; product life cycle; medical value; risk management; quality control; controlled risks. 